\title{
Neutropenic Fever in the Intensive Care Unit
}

\author{
R. Scott Stephens
}

\section{Contents}

\begin{tabular}{|c|c|}
\hline troduction & 1298 \\
\hline Etiology & 1298 \\
\hline Epidemiology ..... & 1298 \\
\hline Neutropenic Fever... & 1298 \\
\hline Neutropenic Sepsis ..... & 299 \\
\hline Pathophysiology ............. & 1299 \\
\hline Clinical Features. & 1301 \\
\hline Diagnosis ....... & 1301 \\
\hline Management . & 1303 \\
\hline Pharmacologic ............... & 1303 \\
\hline Non-pharmacologic ............ & 1305 \\
\hline Management Algorithm $\ldots \ldots \ldots \ldots \ldots \ldots \ldots \ldots \ldots \ldots \ldots \ldots$ & 1305 \\
\hline Prognosis . & 1305 \\
\hline Conclusion and Summary ... & 130 \\
\hline References & \\
\hline
\end{tabular}

\section{Abstract}

Neutropenic fever is a common and potentially life-threatening condition in patients treated for cancer. Rapid initiation of appropriate antimicrobial therapy is necessary to decrease the risk of mortality. Most infections are due to gram-positive organisms, but the mortality rate is

\section{R. S. Stephens $(\bowtie)$}

Oncology and Bone Marrow Transplant Critical Care, Division of Pulmonary and Critical Care Medicine, Johns Hopkins University, Baltimore, MD, USA e-mail: rsteph13@jhmi.edu higher for gram-negative infections. Multidrugresistant organisms are an emerging threat to neutropenic patients. Increasing data suggest that the pathophysiology of neutropenic fever and neutropenic sepsis is substantially different from non-neutropenic fever and sepsis. Additional research is needed to both further elucidate the pathogenesis of neutropenic fever and to develop additional effective antimicrobials.

\section{Keywords}

Neutropenia $\cdot$ Neutropenic $\cdot$ Fever $\cdot$ Sepsis · Gram negative $\cdot$ Gram positive $\cdot$ Fungal 


\section{Introduction}

Neutropenic fever is one of the defining conditions of oncologic critical care. Neutropenic fever is defined as a single temperature higher than $38.3{ }^{\circ} \mathrm{C}$ or a sustained temperature greater than $38.0{ }^{\circ} \mathrm{C}$ for more than $1 \mathrm{~h}$, in the presence of an absolute neutrophil count [ANC]) less than 1500 cells $/ \mathrm{mm}^{3}$, though many centers and guidelines use an ANC cutoff of less than 500 cells $/ \mathrm{mm}^{3}$ $[28,33]$. Exceedingly common in patients receiving cytotoxic chemotherapy, neutropenic fever is a medical emergency which requires urgent initiation of broad-spectrum antibiotics. Any oncologic patient receiving myelosuppressive chemotherapy is at risk of developing neutropenia and opportunistic infections, but profound neutropenia with life-threatening infectious complications is most commonly seen in patients with hematologic malignancies. This can occur during aplasia and before engraftment in patients receiving hematopoietic stem cell transplant (HSCT) or from disease-related or treatment-induced cytopenias in other hematologic malignancy patients.

\section{Etiology}

While there are many potential causes of fevers in neutropenic hosts, both infectious and noninfectious, fevers must be presumed to be infectious in origin. Potential infectious agents and sources of infection are legion and include viruses, bacteria, and fungus. Viral pathogens include respiratory viruses (e.g., respiratory syncytial virus, rhinovirus, adenovirus, coronavirus, influenza, parainfluenza), reactivated or de novo herpes viruses (e.g., herpes simplex, cytomegalovirus, Epstein-Barr virus), and many other potential candidates. Bacterial infections may arise from gut translocation, oral mucosal translocation, infection of indwelling vascular catheters, skin and soft tissue infections, pneumonias, and urinary sources. Fungal infections typically arise from gut translocation, fungal pneumonias (e.g., aspergillosis), and vascular catheters. Drug fevers or "tumor fevers" are the most common example of noninfectious fevers, but these are diagnoses of exclusion.

\section{Epidemiology}

\section{Neutropenic Fever}

Neutropenic fever occurs in up to $50 \%$ of patients with solid tumors receiving cytotoxic chemotherapy and in more than $80 \%$ of patients receiving chemotherapy for hematologic malignancies or undergoing HSCT [28]. In 2012, more than 90,000 adults were hospitalized for cancer-related neutropenia, with a total cost of $\$ 2.3$ billion [75]. In-hospital mortality for all patients admitted with neutropenic fever is nearly $10 \%$; this increases to a hospital mortality rate of more than $15 \%$ for patients with leukemia admitted for neutropenic fever [37].

Bacteremia is documented in up to $25 \%$ of neutropenic fever patients [28]. Whereas in the past gram-negative organisms were commonly cultured, gram-positive organisms, including staphylococci, enterococci, and streptococci, are currently the most commonly isolated bacteria $[28,50]$ (Table 1). This shift is presumably due to the increased use of long-term indwelling vascular catheters and may also be affected by increased use of prophylaxis against gram-

Table 1 Typical pathogens during bacterial sepsis in neutropenic patients

\begin{tabular}{l|l}
\hline Origin & Frequent pathogens \\
\hline Unknown & $\begin{array}{l}\text { Coagulase-negative Staphylococci, } \\
\text { Escherichia coli, Enterococcus } \\
\text { species }\end{array}$ \\
\hline Lung & $\begin{array}{l}\text { Pseudomonas aeruginosa, } \\
\text { Streptococcus pneumonia, Viridans } \\
\text { streptococci, Acinetobacter species }\end{array}$ \\
\hline Abdomen & $\begin{array}{l}\text { Escherichia coli, Pseudomonas } \\
\text { aeruginosa, } \text { Clostridium } \text { species, } \\
\text { Enterococcus species, Klebsiella } \\
\text { species }\end{array}$ \\
\hline Urogenital & $\begin{array}{l}\text { Escherichia coli, Pseudomonas } \\
\text { aeruginosa, } \text { Klebsiella } \text { species }\end{array}$ \\
\hline Soft tissue & $\begin{array}{l}\text { Staphylococcus aureus, alpha- } \\
\text { hemolytic } \text { streptococci }\end{array}$ \\
\hline central venous & $\begin{array}{l}\text { Coagulase-negative Staphylococci, } \\
\text { Coryneform bacteria, } \\
\text { Propionibacterium } \text { species, Candida } \\
\text { albicans, Candida tropicalis, } \\
\text { Candida parapsilosis, } \\
\text { Stenotrophomonas maltophilia }\end{array}$ \\
\hline
\end{tabular}

Modified from [57] (Springer) 
negative organisms $[50,59]$. Though grampositive infections are more common, gramnegative infections confer a higher risk of mortality [77]. Fungal infections, particularly Candida and Aspergillus, are also frequent, especially in patients with prolonged or profound neutropenia [33]. Respiratory viruses can be isolated in approximately $20 \%$ of patients [34]. Despite best efforts, no causative organism can be identified in about $50 \%$ of cases of neutropenic fever [28, 33].

\section{Neutropenic Sepsis}

Sepsis has been most recently defined as "lifethreatening organ dysfunction caused by a dysregulated host response to infection" [70]. A premium is placed on identification of organ dysfunction using either the Sequential Organ Failure Assessment (SOFA) score or the Quick SOFA (qSOFA) score; the presence of organ dysfunction in the setting of a suspected or proven infection is sufficient to diagnose sepsis (Tables 2 and 3). Septic shock is defined by the need for vasopressors to maintain a mean arterial pressure (MAP) $\geq 65 \mathrm{mmHg}$ or a serum lactate $>2 \mathrm{mmol} / \mathrm{L}$ despite adequate volume resuscitation.

There is no specific consensus definition for neutropenic sepsis, other than sepsis occurring in the presence of neutropenia. Any evidence of organ dysfunction, including an elevated lactate, in the presence of neutropenia should be treated as a potential indicator of sepsis. There are few reliable data on the incidence of neutropenic sepsis or neutropenic septic shock. It has been estimated that $50 \%$ of patients with neutropenic fever will develop sepsis, and up to $10 \%$ of patients with neutropenic fever will progress to septic shock [33]. Among neutropenic allogeneic HSCT patients, approximately $10 \%$ will develop severe sepsis during the engraftment period [38].

\section{Pathophysiology}

Cytotoxic chemotherapy or cytotoxic radiation, whether given as an antitumor agent or conditioning regimen for HSCT, induces neutropenia by injuring or destroying hematopoietic precursor cells within the bone marrow as well as injuring the bone marrow structure itself [44]. Circulating

Table 2 Sequential organ failure assessment score

\begin{tabular}{|c|c|c|c|c|c|}
\hline & Score & & & & \\
\hline System & 0 & 1 & 2 & 3 & 4 \\
\hline $\begin{array}{l}\text { Respiration: } \\
\mathrm{PaO}_{2} / \mathrm{FiO}_{2} \\
\mathrm{mmHg}\end{array}$ & $\geq 400$ & $<400$ & $<300$ & $<200^{\mathrm{a}}$ & $<100^{\mathrm{a}}$ \\
\hline $\begin{array}{l}\text { Coagulation: } \\
\text { platelets, } \\
\times 10^{3} / \mu \mathrm{L}\end{array}$ & $\geq 150$ & $<150$ & $<100$ & $<50$ & $<20$ \\
\hline $\begin{array}{l}\text { Liver: } \\
\text { bilirubin, } \\
\mathrm{mg} / \mathrm{dL}\end{array}$ & $<1.2$ & $1.2-1.9$ & $2.0-5.9$ & $6.0-11.9$ & $>12$ \\
\hline Cardiovascular & $\begin{array}{l}\text { MAP } \\
\geq 70 \mathrm{mmHg}\end{array}$ & $\begin{array}{l}\text { MAP } \\
<70 \mathrm{~mm} \mathrm{Hg}\end{array}$ & $\begin{array}{l}\text { Dopamine }<5 \\
\text { or dobutamine } \\
\text { (any dose) }\end{array}$ & $\begin{array}{l}\text { Dopamine } 5.1-15 \text { or } \\
\text { epinephrine } \leq 0.1 \text { or } \\
\text { norepinephrine } \leq 0.1\end{array}$ & $\begin{array}{l}\text { Dopamine }>15 \text { or } \\
\text { epinephrine }>0.1 \text { or } \\
\text { norepinephrine }\end{array}$ \\
\hline CNS: GCS & 15 & $13-14$ & $10-12$ & $6-9$ & $<6$ \\
\hline \multicolumn{6}{|l|}{ Renal: } \\
\hline $\begin{array}{l}\text { Creatinine } \\
(\mathrm{mg} / \mathrm{dL})\end{array}$ & \multirow[t]{2}{*}{$<1.2$} & \multirow[t]{2}{*}{$1.2-1.9$} & \multirow[t]{2}{*}{$2.0-3.4$} & $3.5-4.9$ & $>5.0$ \\
\hline $\begin{array}{l}\text { Urine output } \\
\text { (ml/day) }\end{array}$ & & & & $<500$ & $<200$ \\
\hline
\end{tabular}

Modified from Vincent et al. [79]

CNS central nervous system, GCS Glasgow Coma Scale

${ }^{\mathrm{a}}$ With respiratory support, catecholamine doses given as $\mathrm{mcg} / \mathrm{kg} / \mathrm{min}$ 
Table 3 Quick SOFA criteria (qSOFA)

Respiratory rate $\geq 22 / \mathrm{min}$

Altered mentation

Systolic blood pressure $\leq 100 \mathrm{~mm} \mathrm{Hg}$

Modified from [70]

leukocytes are not replaced as they reach the end of their life span, and neutropenia ensues. Circulating neutrophils have a short life span in the peripheral blood [43], so neutropenia develops rapidly after myelosuppressive therapy. Depending on the chemotherapy employed, circulating neutrophils and other white blood cells may also be damaged or destroyed, causing a more rapid leukopenia than regimens which only affect the marrow. Some agents will injure progenitor cells but not primitive stem cells (which re-populate the progenitor cells), whereas other agents will injure all cells in the marrow [44].

In the normal patient with a localized infection, neutrophils are rapidly recruited at the onset of focal infection and are essential to microbial killing and infection control [40, 45]. Neutropenic fever and neutropenic sepsis have historically been thought of as variants of non-neutropenic fever and sepsis, just without an intact immune system, akin to a "fire without firefighters." However, increasing data suggest that the pathophysiology of neutropenic patients is much more complicated than simply an uncontrolled infection [36]. In addition to their key role in the response to localized infections (e.g., pneumonia), in sepsis neutrophils are rapidly recruited to organs (lungs, kidneys, liver) and are thought to contribute to tissue damage and organ dysfunction [45]. Neutrophils also contribute to resolution of injury and tissue repair [36], as well as regulation of the adaptive immune response [40, 76]. Thus neutropenic patients are not only deficient in the immediate response to infection but also have an altered physiology regarding the development of systemic inflammation and sepsis and in the regulation of the immune response to injury and tissue repair. It is increasingly unclear whether neutropenic sepsis (and the organ damage sequelae) is the same disease as non-neutropenic sepsis.
Because cytotoxic chemotherapy is not selective, neutropenic patients are also lymphopenic, thrombocytopenic, and anemic. Lymphocytes, including $\mathrm{T}$ cells, $\mathrm{B}$ cells, and natural killer (NK) cells, have protean roles in the immune system and a broad effect on the response to infection and septic physiology [20, 43]. These cells are also drastically reduced after cytotoxic chemotherapy, and lymphopenia has been associated with an increased risk of death [67, 71]. Adding to the complexity, the kinetics of count recovery and engraftment vary, and reconstitution of all cell lines does not happen simultaneously [11]. Though the total effect of lymphopenia on the pathophysiology of neutropenic fever and infection remains to be fully determined, patients with neutropenic sepsis have different cytokine profiles than patients with non-neutropenic sepsis: neutropenic patients have higher levels of IL-6, IL-8, and G-CSF than non-neutropenic patients [60]. Monocytes are also dysfunctional in neutropenic sepsis, with evidence not only of deactivation of monocytes in peripheral blood but also of deactivation of differentiated pulmonary macrophages in patients with neutropenic sepsis [48, 49].

The implications of pancytopenia for the response to infection extend beyond white blood cells. Most neutropenic patients are thrombocytopenic, and platelets are increasingly recognized to play an important role in the immune response $[23,74]$. Thrombocytopenia is associated with poor outcomes in critical illness, including in sepsis [18]. In addition to secreting mediators and regulators of inflammation, platelets interact with neutrophils and monocytes and play a vital role in the defense against bacterial, viral, and fungal infections via the formation of neutrophil extracellular traps (NETs) [16, 21, 23]. Platelets also play roles in the development and resolution of organ failure in inflammatory states, including sepsis. In particular, thrombocytopenia has been demonstrated to potentiate lung injury [46, $86]$, and platelets may play a role in the pathophysiology of acute kidney injury [23]. While the role of thrombocytopenia in infection remains incompletely elucidated, it seems clear that 
thrombocytopenia is an important factor in the pathophysiology of neutropenic infection.

Other organ systems with relevance to neutropenic infections are also affected by cytotoxic chemotherapy. The most important of these is injury to the mucosal barrier of the intestinal tract $[13,14,78]$. Disruption of this barrier, which can occur throughout the gastrointestinal (GI) tract, creates portals through which enteric pathogens, including bacteria and yeast, can enter the bloodstream. This is an important source of gram-positive, gram-negative, and fungal infections in neutropenic patients. The respiratory system is also affected in neutropenia. Not only are pulmonary macrophages known to be qualitatively dysfunctional in neutropenic sepsis [48, 49], but quantitative cell counts of alveolar macrophages, lymphocytes, and neutrophils are decreased during neutropenia [19]. Neutropenia also appears to adversely affect lung repair after injury [12]. Taken together, these data strongly support the hypothesis that neutropenic sepsis has a significantly different pathophysiology than non-neutropenic sepsis.

\section{Clinical Features}

As defined above, the diagnosis of neutropenic fever requires a single temperature higher than $38.3^{\circ} \mathrm{C}$ or a sustained temperature greater than $38.0{ }^{\circ} \mathrm{C}$ for more than $1 \mathrm{~h}$ in the presence of neutropenia [28,33]. While some patients are asymptomatic in the presence of neutropenic fever, many describe non-specific symptoms (e.g., cough, anorexia, nausea, fatigue, dizziness, myalgias, confusion, behavioral changes). Patients may also present with respiratory symptoms (cough, shortness of breath, sinus pain or drainage) or abdominal symptoms such as pain or diarrhea. Fewer than half of patients will feel feverish, shiver, or have rigors [17]. Presentation to the hospital can be delayed, with one study suggesting a mean delay in presentation of $11 \mathrm{~h}$ and nearly $40 \%$ of patients delaying presentation for more than $12 \mathrm{~h}$ [17]. Though neutropenic patients have higher fevers than non-neutropenic patients, there is no association between peak temperature and mortality. Hypothermia during neutropenic sepsis is associated with worse outcomes [84].

Neutropenic patients with septic shock tend to have more frequently positive blood cultures, more fungal infections, more multidrug-resistant bacterial infections, and higher mortality rates than immunocompetent patients. Compared to non-neutropenic patients, patients with neutropenic sepsis have higher rates of shock and are at higher risk to sustain acute kidney injury [60].

\section{Diagnosis}

Early recognition of neutropenic fever is essential. Regardless of whether neutropenic patients are hospitalized or not, frequent temperature checks are essential to detect fever; outpatients must particularly be educated on the importance of monitoring temperature. Similarly, interventions that might mask fevers (e.g., antipyretics such as acetaminophen) should generally be avoided in neutropenic patients, and clinicians should be aware of other interventions (e.g., steroids, continuous renal replacement therapy) which may suppress fevers. Once a fever is detected, blood cultures should be obtained without delay, and antibiotics initiated as quickly as possible. Diagnostic measures must not interfere with the timely administration of antibiotics. A comprehensive physical exam should be performed and may uncover potential sources of infection (e.g., mouth sores, skin lesions, pulmonary findings, abdominal tenderness or pain).

Blood cultures are essential to the evaluation of neutropenic patients with fever. A minimum of two sets of blood cultures should be drawn upon presentation. Current recommendations suggest obtaining two sets of cultures, including both peripheral blood cultures and cultures from a central venous catheter, if present [28,33]. Additional laboratory studies at presentation should include complete blood count with differential, electrolytes, and markers of renal and hepatic function (creatinine, blood urea nitrogen, transaminases). 
Depending on the clinical scenario, strong consideration should be given to obtaining an arterial blood gas, coagulation studies, and lactate level [33]. Lactate is of particular potential interest, as an elevated level may help detect early evidence of sepsis-induced malperfusion [33, 70]. Other microbiologic studies can be targeted toward patient-specific indicators. For example, urinary symptoms or an abnormal urinalysis should prompt urine cultures. Diarrhea, especially in a patient treated with antibiotics, should prompt evaluation for Clostridium difficile colitis. Fungal markers such as galactomannan or beta-D-glucan may be useful in some patients [33]. Respiratory symptoms or abnormalities on chest imaging should be evaluated with testing for respiratory viruses and sputum culture [28].

Symptom-guided imaging studies comprise an important part of the evaluation of neutropenic fever. Chest computed tomography (CT) scanning should be performed in patients with respiratory symptoms, and potentially asymptomatic patients with cryptic fevers [33]. Plain chest radiographs are of limited utility in this population and should not be routinely obtained in lieu of CT scans [87]. Sinus, head, and abdominal imaging should be performed as indicated $[28,33]$. The use of nuclear medicine techniques such as FDG-PET/ CT to identify foci of infections in febrile neutropenia has been described, but the utility of these techniques has not yet been proven, and remains impractical for current clinical use [80].

As noted above, respiratory symptoms and/or the presence of abnormalities on chest imaging should prompt evaluation for a respiratory infection. In most cases, this can be done noninvasively $[6,8,10]$. Bronchoscopy may be indicated in some patients, but the benefits of potential diagnosis must be weighed against the risk of requiring endotracheal intubation during bronchoscopy. Abdominal symptoms (pain, diarrhea) should lead to consideration of neutropenic enterocolitis, also known as typhlitis, which is an incompletely understood condition of ileocolonic inflammation which can lead to intestinal necrosis and perforation and is associated with a high mortality rate $[63,64]$. Diagnosis requires the presence of neutropenia, bowel wall thickening $>4 \mathrm{~mm}$ over a
$>30 \mathrm{~mm}$ longitudinal distance, fever $>38^{\circ} \mathrm{C}$, and abdominal pain $[31,51,63]$. Specific diagnosis is elusive in many patients, and diagnostic steps should be repeated if no source is found and fevers persist for 72-96 h. Repeat blood cultures and repeat or expanded imaging studies may provide additional diagnostic information.

Risk stratification is an essential part of diagnosis, as it informs immediate management. The Multinational Association of Supportive Care in Cancer (MASCC) score (Table 4) [35] was developed to predict which patients with neutropenic fever may be safely treated as outpatients. A score $\geq 21$ identifies a standard risk patient, whereas a score $<21$ indicates a high-risk patient. Additional criteria for outpatient treatment have been enumerated by Heinz et al. [33]; these focus on signs of clinical and social stability, with particular emphasis placed on expected good adherence to oral medications, adequate social support (the patient does not live alone), and the ability to present to the hospital within $60 \mathrm{~min}$. It should be noted that the MASCC score has limited utility in predicting either the risk of critical illness or ICU outcomes. Other factors which influence risk stratification include the depth and duration of neutropenia, with an ANC $\leq 100$ cells $/ \mathrm{mm}^{3}$ and $>7$ days duration, respectively, being markers of a high-risk patient [28]. Accordingly, neutropenic

Table 4 MASCC score

\begin{tabular}{l|l}
\hline Characteristic & Weight \\
\hline Burden of febrile neutropenia & 5 (no symptoms); \\
& $\begin{array}{l}3 \text { (mod symptoms); } \\
\text { (moribund) }\end{array}$ \\
\hline $\begin{array}{l}\text { No hypotension } \\
\text { (SBP }>90 \mathrm{mmHg} \text { ) }\end{array}$ & 5 \\
\hline No COPD & 4 \\
\hline $\begin{array}{l}\text { Solid tumor } \text { or heme malignancy } \\
\text { with no prior fungal infection }\end{array}$ & 4 \\
\hline $\begin{array}{l}\text { No dehydration requiring IV } \\
\text { fluids }\end{array}$ & 3 \\
\hline Outpatient status & 3 \\
\hline Age $<60$ years & 2 \\
\hline
\end{tabular}

Modified from [35] 
patients with a hematologic malignancy or status post HSCT are almost always higher risk than patients who become neutropenic during the course of cyclic treatment for a solid malignancy. Comorbid conditions should also be integrated into any clinical risk assessment.

\section{Management}

\section{Pharmacologic}

\section{Prophylaxis in Neutropenic Patients Before Neutropenic Fever Develops}

Due to the high risk of infection in neutropenia, many centers provide routine antimicrobial prophylaxis to patients deemed to be at high risk for infection and who are expected to have prolonged periods of profound neutropenia (e.g., ANC $\leq 500$ cells $/ \mathrm{mm}^{3}$ for $>7$ days). The rationale for antibacterial prophylaxis is to reduce the risk of gram-negative infections and streptococcal infection from oral mucositis. In high-risk patients, current guidelines suggest antibacterial prophylaxis with a fluoroquinolone such as ciprofloxacin or levofloxacin, with the latter preferred if severe mucositis is anticipated $[29,30]$. Antifungal prophylaxis against yeast is recommended in highrisk patients (HSCT, chemotherapy for leukemia) with fluconazole, itraconazole, voriconazole, posaconazole, or an echinocandin (caspofungin or micafungin). Anti-mold (Aspergillus) prophylaxis (with voriconazole or posaconazole) is recommended in patients undergoing chemotherapy for leukemia or patients with anticipated very prolonged neutropenia or prior invasive mold infection [28]. Antiviral prophylaxis acyclovir or valacyclovir is recommended for patients who are seropositive for herpes simplex virus (HSV) and for varicella zoster virus (VZV)-seropositive HSCT patients. Finally, leukemia and HSCT patients should receive prophylaxis against Pneumocystis jirovecii pneumonia. These prophylactic antimicrobials may lessen, but do not eliminate the risk infections while neutropenic; thus, patients and caregivers must remain vigilant for the development of fever. Moreover, attention must be paid to the prophylactic regimen, as it will affect the choice of empiric antibiotics for neutropenic fever.

\section{Antimicrobial Therapy in Neutropenic Fever and Sepsis}

Neutropenic fever is a medical emergency, and appropriate empiric antibiotics must be started without delay: within $60 \mathrm{~min}$ of presentation [28, $33,57]$. Some data suggest that even delays in antibiotic administration beyond $30 \mathrm{~min}$ are associated with increased mortality [62]. As noted above, it is desirable to obtain blood cultures if possible before antibiotic initiation, so long as this does not delay antibiotic administration. No other diagnostic maneuvers should be attempted before antibiotic initiation. Empiric antibiotics must cover the common organisms discussed above (Pseudomonas aeruginosa, Staphylococcus aureus, Streptococcal species) and should also be tailored according to prior patient-specific culture data and institutional epidemiology [28, 33]. Appropriate empiric antibiotics include an antipseudomonal penicillin (e.g., piperacillin/ tazobactam), or antipseudomonal cephalosporin (e.g., cefepime), or a carbapenem (imipenem, meropenem) [28, 33]. Some data suggest improved outcomes with prolonged antibiotic infusion times [58] though these data require confirmation. Fluoroquinolones, which are frequently used as prophylactic therapy in neutropenia, should not be used as empiric monotherapy in neutropenic fever due to the possibility of resistance. Though gram-positive organisms are common causes of neutropenic fever, vancomycin is not routinely indicated, but should be added in the presence of suspected catheter-related infection, soft tissue infection, oral mucositis, radiographically proven pneumonia, known colonization with resistant gram-positive organisms (e.g., methicillin-resistant Staphylococcus aureus, penicillin-resistant Streptococcus), or hemodynamic instability [28, 33, 57].

The use of combination antibiotic regimens (defined as dual gram-negative coverage with an antipseudomonal beta-lactam and an aminoglycoside) in neutropenic fever is controversial. Though some studies have suggested a mortality benefit to combination antibiotics [39], 
this has not been a consistent finding, and 2 metaanalyses have shown no benefit to the addition of an aminoglycoside to a beta-lactam and a higher risk of renal failure with combination therapy $[55,56]$. Accordingly, current guidelines for the management of neutropenic fever and sepsis recommend monotherapy with an antipseudomonal beta-lactam unless otherwise dictated by circumstances such as patient allergies, the presence of resistant organisms, or refractory hemodynamic instability [28, 57, 61]. It should be noted, however, that this recommendation does not preclude the use of vancomycin or antifungals; it is only directed at combination therapy targeted against gram-negative bacteria.

Even with appropriate antibiotics, fever in neutropenic patients typically persists for a median of 5 days; thus, ongoing fevers, unless accompanied by clinical instability, should not necessarily be viewed as evidence of failure of antibiotic therapy [73]. In patients with persistent or recurrent fevers after 3-5 days, a modification of antibiotic regimen is reasonable, especially if guided by new or changing clinical data. Earlier antibiotic escalation is necessary in some patients, most commonly in patients with hemodynamic instability. In the face of hemodynamic instability, vancomycin should be added if not already part of the regimen. Additionally, antipseudomonal cephalosporins or penicillins should be escalated to a carbapenem (e.g., meropenem), and strong consideration should be given to the addition of an aminoglycoside, fluoroquinolone, or aztreonam $[28,33,57,61]$.

Drug-resistant and multidrug-resistant (MDR) organisms are an increasing problem in neutropenic infections [26, 29, 50]. Vancomycin-resistant enterococcus (VRE) bacteremia affects a substantial portion (10-35\%) of patients during induction therapy for leukemia or after HSCT and is associated with significantly worse outcomes $[3,53,85]$. Early treatment with agents active against VRE such as linezolid or daptomycin may improve outcomes. Predictive models are being developed to assist with early identification of patients who might benefit from early initiation of antibiotics active against VRE [83]. Similarly, MDR gram-negative infections, particularly carbapenem-resistant Enterobacteriaceae, are associated with high mortality rates, especially among allogeneic HSCT patients [66]. Successful treatment of these infections requires early use of multidrug antibiotic regimens, typically including aminoglycosides, carbapenems, and polymyxins. The use of surveillance rectal cultures, performed pre-transplant and then weekly after HSCT, to identify patients with MDR infections and allow immediate initiation of antibiotic therapy targeted against MDR organisms may result in better outcomes [26].

Fungal pathogens are a constant threat in neutropenic patients, and consideration must be given to the use of antifungal agents in all patients with neutropenic fever. In general, antifungal therapy should be initiated in the setting of persistent fever after 5-7 days of appropriate antibacterials [28, 33]. Appropriate antifungals should have activity against molds, especially aspergillosis; examples include liposomal amphotericin, caspofungin, and voriconazole, though the data are more robust in favor of the former two [33, 81, 82]. Fluconazole should not be used as empiric therapy. An increasing number of neutropenic patients are on antifungal prophylaxis with voriconazole prior to developing fever; the utility of changing antifungal agents upon fever development in this setting is unclear. Antifungals should be strongly considered as early therapy in all patients who are hemodynamically unstable $[28,33]$.

With the advent of multidrug-resistant organisms, antibiotic stewardship is increasingly important, even in neutropenic patients. The optimum duration of antimicrobial therapy in the neutropenic patient and whether antimicrobials may be safely de-escalated in the face of clinical stability are ongoing areas of investigation. One randomized controlled trial suggests that empiric antibiotics may be safely discontinued after a patient has defervesced and remained afebrile for $72 \mathrm{~h}$, regardless of whether neutrophil recovery has occurred [2]. Another recent paper suggested that it is safe to withhold antibacterial therapy in children with neutropenic fever in whom infection with a respiratory virus has been proven [65]. Neither of these tactics has become standard of care, but both highlight the increasingly realized 
importance of antibiotic stewardship, even in neutropenic patients.

\section{Hematopoietic Growth Factors}

Hematopoietic growth factors may be considered in select cases of neutropenic fever, as they have been shown to shorten the duration of neutropenia, but do not impact mortality [22]. According, due to a lack of proven mortality benefit, current guidelines recommend against the routine use of hematopoietic growth factors in neutropenic fever or neutropenic sepsis [29, 72].

\section{Granulocyte Transfusions}

Granulocyte transfusions have been used to support patients with neutropenia, both to prevent infections and to help treat established infections. Very few studies have been performed to evaluate this intervention, and those studies that are available are small. Two recent Cochrane metaanalyses have examined the use of granulocyte transfusions in neutropenic patients to prevent and treat infections, respectively. Both concluded that there was insufficient evidence to determine whether granulocyte transfusions conferred any mortality benefit $[24,25]$.

\section{Non-pharmacologic}

Early and appropriate administration of antimicrobials is essential to preventing death from neutropenic fever and neutropenic sepsis. Good outcomes also depend on successfully managing the hemodynamic derangements and organ failure of sepsis. The intensive care unit (ICU) is the bestsuited location to care for neutropenic patients with sepsis and septic shock, and earlier ICU admission has been associated with improved survival rates $[7,9]$.

Recent guidelines have been published for the management of sepsis and septic shock [61]; these guidelines are also applicable to the management of neutropenic sepsis. Key points include initial resuscitation with at least $30 \mathrm{ml} / \mathrm{kg}$ of intravenous crystalloid with additional fluid resuscitation as indicated and using norepinephrine as a first-line vasopressor to target a mean arterial pressure $\geq 65 \mathrm{~mm} \mathrm{Hg}$. Either vasopressin or epinephrine may be added if the response to norepinephrine is inadequate. There may be benefit to using balanced crystalloid solutions such as lactated Ringer's or PlasmaLyte rather than normal saline $[68,69]$. Source control should be obtained if possible. Though occasionally an abscess may be present and feasible to drain, most commonly, an indwelling central venous catheter is the only addressable source of infection. In the hemodynamically unstable patient with a suspected catheter infection, early catheter removal is associated with improved survival [39]; accordingly, infected or potentially infected catheters should be removed without delay.

Patients with neutropenia and sepsis are at high risk of developing multi-organ failure, particularly the acute respiratory distress syndrome (ARDS) $[4,5]$. The use of noninvasive ventilation in immunosuppressed patients with hypoxemic respiratory failure is increasingly controversial, and heated humidified high-flow oxygen may be a better option [5, 15, 27, 41, 42, 52]. Once patients are intubated, low tidal volume ventilation should be used to maximize lung protection and minimize ventilator-induced lung injury [1]. Adjuncts such as neuromuscular blockade and prone positioning should be used in patients with moderate to severe ARDS (PaO2: FiO2 < 150) $[32,54]$. Mortality for patients who develop ARDS in this context remains high, but outcomes are improving. Attention to best practices for mechanical ventilation is essential.

\section{Management Algorithm}

An algorithm for the empiric management of neutropenic fever can be found in Fig. 1.

\section{Prognosis}

The risk of neutropenic fever and neutropenic sepsis resolves once the bone marrow recovers and neutrophil counts return to normal. If treated appropriately, neutropenic fever is a common, predictable, and manageable complication of 
Neutropenic Fever Empiric Management Algorithm

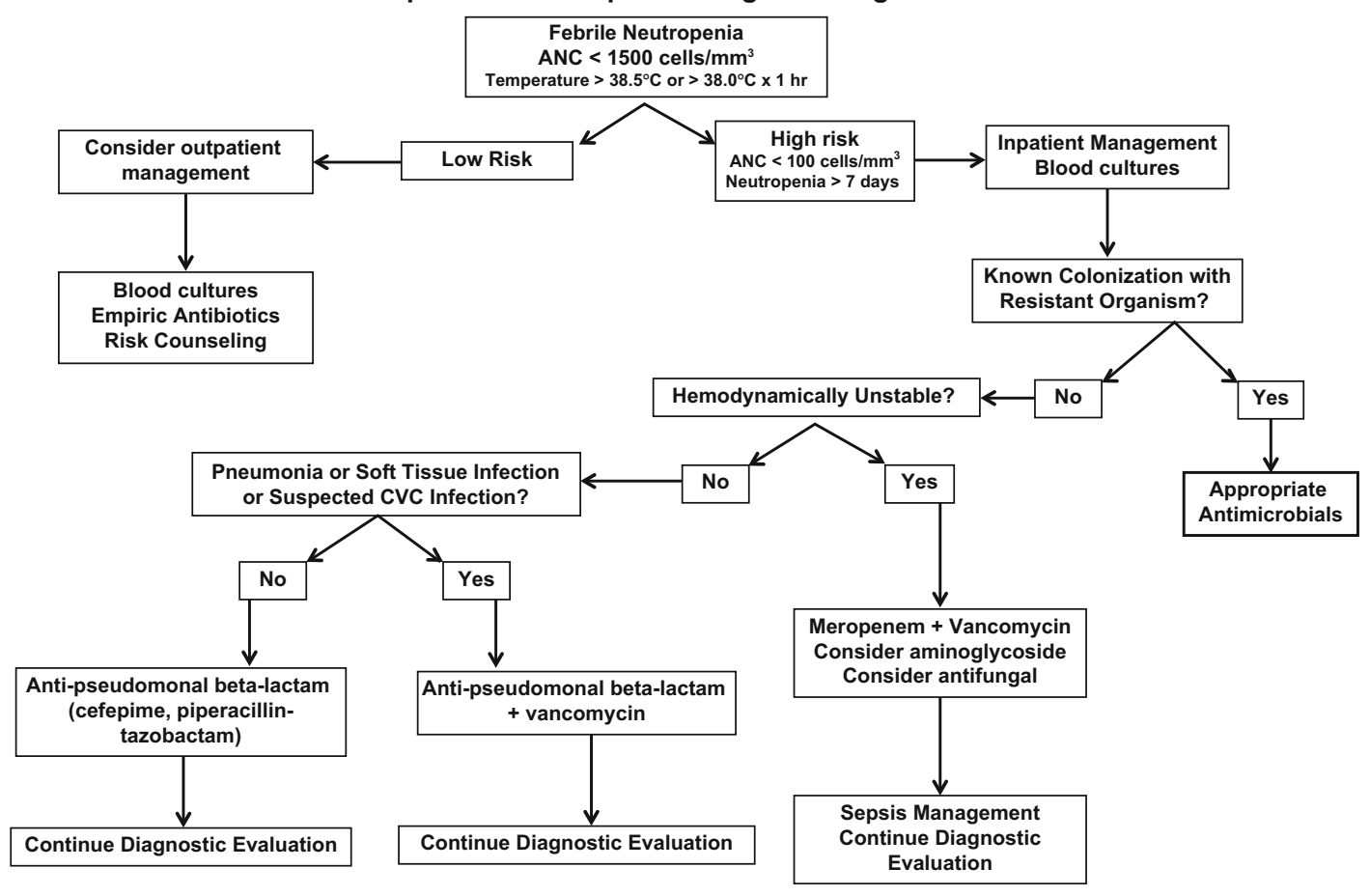

Fig. 1 Empiric Management of Neutropenic Fever

cytotoxic therapy or HSCT. Neutropenic sepsis continues to confer a poor prognosis, with recent data suggesting an approximate $46 \%$ mortality rate in patients with hematologic malignancies who develop septic shock [7, 39, 47]. Predictors of mortality include sepsis after allogeneic HSCT, the presence of graft vs host disease, respiratory failure requiring mechanical ventilation, positive blood cultures, cardiac failure, renal failure, and hepatic failure [38, 47]. Younger age ( $<70$ years) and the presence of neutropenic enterocolitis are associated with improved survival [47].

\section{Conclusion and Summary}

Encouragingly, survival in neutropenic sepsis and septic shock appears to be improving but is still worse than in non-neutropenic septic patients [9, 10, 39]. The emergence of multidrug-resistant organisms is a major concern, and there is an urgent need for novel antibiotics to address this threat. Along these lines, additional work needs to be done to identify patients in whom antibiotic therapy can be safely de-escalated. The pathophysiology of neutropenic sepsis requires further study and efforts made to facilitate earlier diagnosis and identification of pathogens in neutropenic patients. Finally, neutropenic sepsis should be studied as a specific and separate entity from "normal" sepsis, and efficacy of interventions confirmed in this specific population.

\section{References}

1. Acute Respiratory Distress Syndrome, N, Brower RG, Matthay MA, Morris A, Schoenfeld D, Thompson BT, Wheeler A. Ventilation with lower tidal volumes as compared with traditional tidal volumes for acute lung injury and the acute respiratory distress syndrome. N Engl J Med. 2000;342:1301-8.

2. Aguilar-Guisado M, Espigado I, Martin-Pena A, Gudiol C, Royo-Cebrecos C, Falantes J, VazquezLopez L, Montero MI, Rosso-Fernandez C, de la Luz Martino M, Parody R, Gonzalez-Campos J, GarzonLopez S, Calderon-Cabrera C, Barba P, Rodriguez N, Rovira M, Montero-Mateos E, Carratala J, Perez- 
Simon JA, Cisneros JM. Optimisation of empirical antimicrobial therapy in patients with haematological malignancies and febrile neutropenia (how long study): an open-label, randomised, controlled phase 4 trial. Lancet Haematol. 2017;4:e573-83.

3. Avery R, Kalaycio M, Pohlman B, Sobecks R, Kuczkowski E, Andresen S, Mossad S, Shamp J, Curtis J, Kosar J, Sands K, Serafin M, Bolwell B. Early vancomycin-resistant enterococcus (VRE) bacteremia after allogeneic bone marrow transplantation is associated with a rapidly deteriorating clinical course. Bone Marrow Transplant. 2005;35:497-9.

4. Azoulay E, Darmon M. Acute respiratory distress syndrome during neutropenia recovery. Crit Care. 2010;14:114

5. Azoulay E, Lemiale V, Mokart D, Pene F, Kouatchet A, Perez P, Vincent F, Mayaux J, Benoit D, Bruneel F, Meert AP, Nyunga M, Rabbat A, Darmon M. Acute respiratory distress syndrome in patients with malignancies. Intensive Care Med. 2014;40:1106-14.

6. Azoulay E, Mokart D, Lambert J, Lemiale V, Rabbat A, Kouatchet A, Vincent F, Gruson D, Bruneel F, Epinette-Branche G, Lafabrie A, Hamidfar-Roy R, Cracco C, Renard B, Tonnelier JM, Blot F, Chevret S, Schlemmer B. Diagnostic strategy for hematology and oncology patients with acute respiratory failure: randomized controlled trial. Am J Respir Crit Care Med. 2010;182:1038-46.

7. Azoulay E, Mokart D, Pene F, Lambert J, Kouatchet A, Mayaux J, Vincent F, Nyunga M, Bruneel F, Laisne LM, Rabbat A, Lebert C, Perez P, Chaize M, Renault A, Meert AP, Benoit D, Hamidfar R, Jourdain M, Darmon M, Schlemmer B, Chevret S, Lemiale V. Outcomes of critically ill patients with hematologic malignancies: prospective multicenter data from France and Belgium - a groupe de recherche respiratoire en reanimation onco-hematologique study. J Clin Oncol. 2013;31:2810-8.

8. Azoulay E, Mokart D, Rabbat A, Pene F, Kouatchet A, Bruneel F, Vincent F, Hamidfar R, Moreau D, Mohammedi I, Epinette G, Beduneau G, Castelain V, de Lassence A, Gruson D, Lemiale V, Renard B, Chevret S, Schlemmer B. Diagnostic bronchoscopy in hematology and oncology patients with acute respiratory failure: prospective multicenter data. Crit Care Med. 2008;36:100-7

9. Azoulay E, Pene F, Darmon M, Lengline E, Benoit D, Soares M, Vincent F, Bruneel F, Perez P, Lemiale V, Mokart D, Groupe de Recherche Respiratoire en Reanimation, O.-H. Managing critically ill hematology patients: time to think differently. Blood Rev. 2015;29:359-67.

10. Azoulay E, Schellongowski P, Darmon M, Bauer PR, Benoit D, Depuydt P, Divatia JV, Lemiale V, van Vliet M, Meert AP, Mokart D, Pastores SM, Perner A, Pene F, Pickkers P, Puxty KA, Vincent F, Salluh J, Soubani AO, Antonelli M, Staudinger T, von Bergwelt-Baildon M, Soares M. The intensive care medicine research agenda on critically ill oncology and hematology patients. Intensive Care Med. 2017;43:1366-82.

11. Baron F, Little MT, Storb R. Kinetics of engraftment following allogeneic hematopoietic cell transplantation with reduced-intensity or nonmyeloablative conditioning. Blood Rev. 2005;19:153-64.

12. Blazquez-Prieto J, Lopez-Alonso I, AmadoRodriguez L, Huidobro C, Gonzalez-Lopez A, Kuebler WM, Albaiceta GM. Impaired lung repair during neutropenia can be reverted by matrix metalloproteinase- 9 . Thorax. 2018;73:321-30.

13. Blijlevens NM, Donnelly JP, de Pauw BE. Mucosal barrier injury: biology, pathology, clinical counterparts and consequences of intensive treatment for haematological malignancy: an overview. Bone Marrow Transplant. 2000;25:1269-78.

14. Blijlevens NM, Donnelly JP, Depauw BE. Inflammatory response to mucosal barrier injury after myeloablative therapy in allogeneic stem cell transplant recipients. Bone Marrow Transplant. 2005;36:703-7.

15. Carteaux G, Millan-Guilarte T, de Prost N, Razazi K, Abid S, Thille AW, Schortgen F, Brochard L, BrunBuisson C, Dessap AM. Failure of noninvasive ventilation for de novo acute hypoxemic respiratory failure: role of tidal volume. Crit Care Med. 2016;44:282-90.

16. Clark SR, Ma AC, Tavener SA, McDonald B, Goodarzi Z, Kelly MM, Patel KD, Chakrabarti S, McAvoy E, Sinclair GD, Keys EM, Allen-Vercoe E, Devinney R, Doig CJ, Green FH, Kubes P. Platelet TLR4 activates neutrophil extracellular traps to ensnare bacteria in septic blood. Nat Med. 2007;13:463-9.

17. Clarke RT, Bird S, Kakuchi I, Littlewood TJ, van Hamel Parsons V. The signs, symptoms and helpseeking experiences of neutropenic sepsis patients before they reach hospital: a qualitative study. Support Care Cancer. 2015;23:2687-94.

18. Claushuis TA, van Vught LA, Scicluna BP, Wiewel MA, Klein Klouwenberg PM, Hoogendijk AJ, Ong DS, Cremer OL, Horn J, Franitza M, Toliat MR, Nurnberg P, Zwinderman AH, Bonten MJ, Schultz MJ, van der Poll T, Molecular, D. \& Risk Stratification of Sepsis, C. Thrombocytopenia is associated with a dysregulated host response in critically ill sepsis patients. Blood. 2016;127:3062-72.

19. Cordonnier C, Escudier E, Verra F, Brochard L, Bernaudin JF, Fleury-Feith J. Bronchoalveolar lavage during neutropenic episodes: diagnostic yield and cellular pattern. Eur Respir J. 1994;7:114-20.

20. de Pablo R, Monserrat J, Prieto A, Alvarez-Mon M. Role of circulating lymphocytes in patients with sepsis. Biomed Res Int. 2014;2014:671087.

21. de Stoppelaar SF, van't Veer C, Claushuis TAM, Albersen BJA, Roelofs JJTH, van der Poll T. Thrombocytopenia impairs host defense in gramnegative pneumonia-derived sepsis in mice. Blood. 2014;124:3781-90. 
22. Dekker A, Bulley S, Beyene J, Dupuis LL, Doyle JJ, Sung L. Meta-analysis of randomized controlled trials of prophylactic granulocyte colony-stimulating factor and granulocyte-macrophage colony-stimulating factor after autologous and allogeneic stem cell transplantation. J Clin Oncol. 2006;24:5207-15.

23. Dewitte A, Lepreux S, Villeneuve J, Rigothier C, Combe C, Ouattara A, Ripoche J. Blood platelets and sepsis pathophysiology: a new therapeutic prospect in critical ill patients? Ann Intensive Care. 2017;7:115.

24. Estcourt LJ, Stanworth S, Doree C, Blanco P, Hopewell S, Trivella M, Massey E. Granulocyte transfusions for preventing infections in people with neutropenia or neutrophil dysfunction. Cochrane Database Syst Rev. 2015;6:CD005341.

25. Estcourt LJ, Stanworth SJ, Hopewell S, Doree C, Trivella M, Massey E. Granulocyte transfusions for treating infections in people with neutropenia or neutrophil dysfunction. Cochrane Database Syst Rev. 2016;4:CD005339.

26. Forcina A, Lorentino F, Marasco V, Oltolini C, Marcatti M, Greco R, Lupo-Stanghellini MT, Carrabba M, Bernardi M, Peccatori J, Corti C, Ciceri F. Clinical impact of pretransplant multidrug-resistant gram-negative colonization in autologous and allogeneic hematopoietic stem cell transplantation. Biol Blood Marrow Transplant. 2018;24:1476-82.

27. Frat JP, Thille AW, Mercat A, Girault C, Ragot S, Perbet S, Prat G, Boulain T, Morawiec E, Cottereau A, Devaquet J, Nseir S, Razazi K, Mira JP, Argaud L, Chakarian JC, Ricard JD, Wittebole X, Chevalier S, Herbland A, Fartoukh M, Constantin JM, Tonnelier JM, Pierrot M, Mathonnet A, Beduneau G, Deletage-Metreau C, Richard JCM, Brochard L, Robert R, GRP, F. S, Network, R. Highflow oxygen through nasal cannula in acute hypoxemic respiratory failure. N Engl J Med. 2015;372:2185-96.

28. Freifeld AG, Bow EJ, Sepkowitz KA, Boeckh MJ, Ito JI, Mullen CA, Raad II, Rolston KV, Young JA, Wingard JR, Infectious Diseases Society of, A. Clinical practice guideline for the use of antimicrobial agents in neutropenic patients with cancer: 2010 update by the Infectious Diseases Society of America. Clin Infect Dis. 2011a;52:427-31.

29. Freifeld AG, Bow EJ, Sepkowitz KA, Boeckh MJ, Ito JI, Mullen CA, Raad II, Rolston KV, Young JA, Wingard JR, Infectious Diseases Society of, A. Clinical practice guideline for the use of antimicrobial agents in neutropenic patients with cancer: 2010 update by the Infectious Diseases Society of America. Clin Infect Dis. 2011b;52:e56-93.

30. Gafter-Gvili A, Fraser A, Paul M, Vidal L, Lawrie TA, van de Wetering MD, Kremer LC, Leibovici L. Antibiotic prophylaxis for bacterial infections in afebrile neutropenic patients following chemotherapy. Cochrane Database Syst Rev. 2012;1:CD004386.

31. Gorschluter M, Mey U, Strehl J, Ziske C, Schepke M, Schmidt-Wolf IG, Sauerbruch T, Glasmacher A. Neutropenic enterocolitis in adults: systematic analysis of evidence quality. Eur J Haematol. 2005; $75: 1-13$.

32. Guerin C, Reignier J, Richard JC, Beuret P, Gacouin A, Boulain T, Mercier E, Badet M, Mercat A, Baudin O, Clavel M, Chatellier D, Jaber S, Rosselli S, Mancebo J, Sirodot M, Hilbert G, Bengler C, Richecoeur J, Gainnier M, Bayle F, Bourdin G, Leray V, Girard R, Baboi L, Ayzac L. Prone positioning in severe acute respiratory distress syndrome. $\mathrm{N}$ Engl $\mathrm{J}$ Med. 2013;368:2159-68.

33. Heinz WJ, Buchheidt D, Christopeit M, von LilienfeldToal M, Cornely OA, Einsele H, Karthaus M, Link H, Mahlberg R, Neumann S, Ostermann H, Penack O, Ruhnke M, Sandherr M, Schiel X, Vehreschild JJ, Weissinger F, Maschmeyer G. Diagnosis and empirical treatment of fever of unknown origin (FUO) in adult neutropenic patients: guidelines of the Infectious Diseases Working Party (AGIHO) of the German Society of Hematology and Medical Oncology (DGHO). Ann Hematol. 2017;96:1775-92.

34. Jansen RR, Biemond BJ, Schinkel J, Koekkoek SM, Molenkamp R, de Jong MD, Visser CE. Febrile neutropenia: significance of elaborated screening for respiratory viruses, and the comparison of different sampling methods, in neutropenic patients with hematological malignancies. Virol J. 2013;10:212.

35. Klastersky J, Paesmans M, Rubenstein EB, Boyer M, Elting L, Feld R, Gallagher J, Herrstedt J, Rapoport B, Rolston K, Talcott J. The Multinational Association for Supportive Care in Cancer risk index: a multinational scoring system for identifying low-risk febrile neutropenic cancer patients. J Clin Oncol. 2000;18:3038-51.

36. Kolaczkowska E, Kubes P. Neutrophil recruitment and function in health and inflammation. Nat Rev Immunol. 2013;13:159-75.

37. Kuderer NM, Dale DC, Crawford J, Cosler LE, Lyman GH. Mortality, morbidity, and cost associated with febrile neutropenia in adult cancer patients. Cancer. 2006;106:2258-66.

38. Kumar G, Ahmad S, Taneja A, Patel J, Guddati AK, Nanchal R, Milwaukee Initiative in Critical Care Outcomes Research Group of, I. Severe sepsis in hematopoietic stem cell transplant recipients*. Crit Care Med. 2015;43:411-21.

39. Legrand M, Max A, Peigne V, Mariotte E, Canet E, Debrumetz A, Lemiale V, Seguin A, Darmon M, Schlemmer B, Azoulay E. Survival in neutropenic patients with severe sepsis or septic shock. Crit Care Med. 2012;40:43-9.

40. Leliefeld PH, Wessels CM, Leenen LP, Koenderman L, Pillay J. The role of neutrophils in immune dysfunction during severe inflammation. Crit Care. 2016;20:73.

41. Lemiale V, Mokart D, Resche-Rigon M, Pene F, Mayaux J, Faucher E, Nyunga M, Girault C, Perez P, Guitton C, Ekpe K, Kouatchet A, Theodose I, Benoit D, Canet E, Barbier F, Rabbat A, Bruneel F, Vincent F, Klouche K, Loay K, Mariotte E, Bouadma L, Moreau AS, Seguin A, Meert AP, Reignier J, Papazian L, Mehzari I, Cohen Y, 
Schenck M, Hamidfar R, Darmon M, Demoule A, Chevret S, Azoulay E, Groupe de Recherche en Reanimation Respiratoire du Patient, D. O.-H. Effect of noninvasive ventilation vs oxygen therapy on mortality among immunocompromised patients with acute respiratory failure: a randomized clinical trial. JAMA. 2015a;314:1711-9.

42. Lemiale V, Resche-Rigon M, Mokart D, Pene F, Rabbat A, Kouatchet A, Vincent F, Bruneel F, Nyunga M, Lebert C, Perez P, Meert AP, Benoit D, Chevret S, Azoulay E. Acute respiratory failure in patients with hematological malignancies: outcomes according to initial ventilation strategy. A groupe de recherche respiratoire en reanimation oncohematologique (Grrr-OH) study. Ann Intensive Care. 2015b;5:28.

43. Luan YY, Dong N, Xie M, Xiao XZ, Yao YM. The significance and regulatory mechanisms of innate immune cells in the development of sepsis. J Interf Cytokine Res. 2014;34:2-15.

44. Mauch P, Constine L, Greenberger J, Knospe W, Sullivan J, Liesveld JL, Deeg HJ. Hematopoietic stem cell compartment: acute and late effects of radiation therapy and chemotherapy. Int J Radiat Oncol Biol Phys. 1995;31:1319-39.

45. McDonald B. Neutrophils in critical illness. Cell Tissue Res. 2018;371:607-15.

46. Middleton EA, Weyrich AS, Zimmerman GA. Platelets in pulmonary immune responses and inflammatory lung diseases. Physiol Rev. 2016;96:1211-59.

47. Mokart D, Darmon M, Resche-Rigon M, Lemiale V, Pene F, Mayaux J, Rabbat A, Kouatchet A, Vincent F, Nyunga M, Bruneel F, Lebert C, Perez P, Renault A, Hamidfar R, Jourdain M, Meert AP, Benoit D, Chevret S, Azoulay E. Prognosis of neutropenic patients admitted to the intensive care unit. Intensive Care Med. 2015;41:296-303.

48. Mokart D, Guery BP, Bouabdallah R, Martin C, Blache JL, Arnoulet C, Mege JL. Deactivation of alveolar macrophages in septic neutropenic ARDS. Chest. 2003;124:644-52.

49. Mokart D, Kipnis E, Guerre-Berthelot P, Vey N, Capo C, Sannini A, Brun JP, Blache JL, Mege JL, Blaise D, Guery BP. Monocyte deactivation in neutropenic acute respiratory distress syndrome patients treated with granulocyte colony-stimulating factor. Crit Care. 2008;12:R17.

50. Montassier E, Batard E, Gastinne T, Potel G, de la Cochetiere MF. Recent changes in bacteremia in patients with cancer: a systematic review of epidemiology and antibiotic resistance. Eur J Clin Microbiol Infect Dis. 2013;32:841-50.

51. Nesher L, Rolston KV. Neutropenic enterocolitis, a growing concern in the era of widespread use of aggressive chemotherapy. Clin Infect Dis. 2013;56:711-7.

52. Neuschwander A, Lemiale V, Darmon M, Pene F, Kouatchet A, Perez P, Vincent F, Mayaux J, Benoit D, Bruneel F, Meert AP, Nyunga M, Rabbat A, Mokart D, Azoulay E, Study, A. G. D. R.
E. R. R. E. O.-H. Noninvasive ventilation during acute respiratory distress syndrome in patients with cancer: trends in use and outcome. J Crit Care. 2017;38:295-9.

53. Ornstein MC, Mukherjee S, Keng M, Elson P, Tiu RV, Saunthararajah Y, Maggiotto A, Schaub M, Banks D, Advani A, Kalaycio M, Maciejewski JP, Sekeres MA. Impact of vancomycin-resistant enterococcal bacteremia on outcome during acute myeloid leukemia induction therapy. Leuk Lymphoma. 2015;56:2536-42.

54. Papazian L, Forel JM, Gacouin A, Penot-Ragon C, Perrin G, Loundou A, Jaber S, Arnal JM, Perez D, Seghboyan JM, Constantin JM, Courant P, Lefrant JY, Guerin C, Prat G, Morange S, Roch A. Neuromuscular blockers in early acute respiratory distress syndrome. N Engl J Med. 2010;363:1107-16.

55. Paul M, Dickstein Y, Schlesinger A, GrozinskyGlasberg S, Soares-Weiser K, Leibovici L. Beta-lactam versus beta-lactam-aminoglycoside combination therapy in cancer patients with neutropenia. Cochrane Database Syst Rev. 2013; CD003038.

56. Paul M, Soares-Weiser K, Leibovici L. Beta lactam monotherapy versus beta lactam-aminoglycoside combination therapy for fever with neutropenia: systematic review and meta-analysis. BMJ. 2003;326:1111.

57. Penack O, Becker C, Buchheidt D, Christopeit M, Kiehl $M$, von Lilienfeld-Toal $M$, Hentrich $M$, Reinwald M, Salwender H, Schalk E, Schmidt-HieberM, Weber T, Ostermann H. Management of sepsis in neutropenic patients: 2014 updated guidelines from the Infectious Diseases Working Party of the German Society of Hematology and Medical Oncology (AGIHO). Ann Hematol. 2014;93:1083-95.

58. Ram R, Halavy Y, Amit O, Paran Y, Katchman E, Yachini B, Kor S, Avivi I, Ben-Ami R. Extended versus bolus infusion of broad spectrum beta-lactams for febrile neutropenia: an unblinded randomized trial. Clin Infect Dis. 2018;67:1153-60.

59. Ramphal R. Changes in the etiology of bacteremia in febrile neutropenic patients and the susceptibilities of the currently isolated pathogens. Clin Infect Dis. 2004;39(Suppl 1):S25-31.

60. Reilly JP, Anderson BJ, Hudock KM, Dunn TG, Kazi A, Tommasini A, Charles D, Shashaty MG, Mikkelsen ME, Christie JD, Meyer NJ. Neutropenic sepsis is associated with distinct clinical and biological characteristics: a cohort study of severe sepsis. Crit Care. 2016;20:222.

61. Rhodes A, Evans LE, Alhazzani W, Levy MM, Antonelli M, Ferrer R, Kumar A, Sevransky JE, Sprung CL, Nunnally ME, Rochwerg B, Rubenfeld GD, Angus DC, Annane D, Beale RJ, Bellinghan GJ, Bernard GR, Chiche JD, Coopersmith C, de Backer DP, French CJ, Fujishima S, Gerlach H, Hidalgo JL, Hollenberg SM, Jones AE, Karnad DR, Kleinpell RM, Koh Y, Lisboa TC, Machado FR, Marini JJ, Marshall JC, Mazuski JE, McIntyre LA, McLean AS, Mehta S, Moreno RP, Myburgh J, Navalesi P, Nishida O, Osborn TM, Perner A, Plunkett CM, Ranieri M, Schorr CA, Seckel MA, Seymour CW, Shieh L, Shukri KA, 
Simpson SQ, Singer M, Thompson BT, Townsend SR, van der Poll T, Vincent JL, Wiersinga WJ, Zimmerman JL, Dellinger RP. Surviving sepsis campaign: international guidelines for management of sepsis and septic shock: 2016. Crit Care Med. 2017;45:486-552.

62. Rosa RG, Goldani LZ. Cohort study of the impact of time to antibiotic administration on mortality in patients with febrile neutropenia. Antimicrob Agents Chemother. 2014;58:3799-803.

63. Sachak T, Arnold MA, Naini BV, Graham RP, Shah SS, Cruise M, Park JY, Clark L, Lamps L, Frankel WL, Theodoropoulos N, Arnold CA. Neutropenic enterocolitis: new insights into a deadly entity. Am J Surg Pathol. 2015;39:1635-42.

64. Saillard C, Zafrani L, Darmon M, Bisbal M, ChowChine L, Sannini A, Brun JP, Ewald J, Turrini O, Faucher M, Azoulay E, Mokart D. The prognostic impact of abdominal surgery in cancer patients with neutropenic enterocolitis: a systematic review and meta-analysis, on behalf the Groupe de Recherche en Reanimation Respiratoire du patient d'OncoHematologie (GRRR-OH). Ann Intensive Care. 2018;8:47.

65. Santolaya ME, Alvarez AM, Acuna M, Aviles CL, Salgado C, Tordecilla J, Varas M, Venegas M, Villarroel M, Zubieta M, Toso A, Bataszew A, Farfan MJ, de la Maza V, Vergara A, Valenzuela R, Torres JP. Efficacy and safety of withholding antimicrobial treatment in children with cancer, fever and neutropenia, with a demonstrated viral respiratory infection: a randomized clinical trial. Clin Microbiol Infect. 2017;23:173-8.

66. Satlin MJ, Jenkins SG, Walsh TJ. The global challenge of carbapenem-resistant Enterobacteriaceae in transplant recipients and patients with hematologic malignancies. Clin Infect Dis. 2014;58:1274-83.

67. Savani BN, Mielke S, Rezvani K, Montero A, Yong AS, Wish L, Superata J, Kurlander R, Singh A, Childs R, Barrett AJ. Absolute lymphocyte count on day 30 is a surrogate for robust hematopoietic recovery and strongly predicts outcome after $\mathrm{T}$ cell-depleted allogeneic stem cell transplantation. Biol Blood Marrow Transplant. 2007;13:1216-23.

68. Self WH, Semler MW, Wanderer JP, Wang L, Byrne DW, Collins SP, Slovis CM, Lindsell CJ, Ehrenfeld JM, Siew ED, Shaw AD, Bernard GR, Rice TW, Investigators, S.-E. Balanced crystalloids versus saline in noncritically ill adults. $\mathrm{N}$ Engl $\mathrm{J}$ Med. 2018;378:819-28.

69. Semler MW, Self WH, Wanderer JP, Ehrenfeld JM, Wang L, Byrne DW, Stollings JL, Kumar AB, Hughes CG, Hernandez A, Guillamondegui OD, May AK, Weavind L, Casey JD, Siew ED, Shaw AD, Bernard GR, Rice TW, Investigators, S, The Pragmatic Critical Care Research, G. Balanced crystalloids versus saline in critically ill adults. N Engl J Med. 2018;378:829-39.

70. Singer M, Deutschman CS, Seymour CW, ShankarHari M, Annane D, Bauer M, Bellomo R, Bernard GR, Chiche JD, Coopersmith CM, Hotchkiss RS, Levy MM, Marshall JC, Martin GS, Opal SM, Rubenfeld GD, van der Poll T, Vincent JL, Angus
DC. The third international consensus definitions for sepsis and septic shock (sepsis-3). JAMA. 2016;315:801-10.

71. Small TN, Papadopoulos EB, Boulad F, Black P, Castro-Malaspina H, Childs BH, Collins N, Gillio A, George D, Jakubowski A, Heller G, Fazzari M, Kernan N, Mackinnon S, Szabolcs P, Young JW, O'Reilly RJ. Comparison of immune reconstitution after unrelated and related T-cell-depleted bone marrow transplantation: effect of patient age and donor leukocyte infusions. Blood. 1999;93:467-80.

72. Smith TJ, Bohlke K, Lyman GH, Carson KR, Crawford J, Cross SJ, Goldberg JM, Khatcheressian JL, Leighl NB, Perkins CL, Somlo G, Wade JL, Wozniak AJ, Armitage JO, American Society of Clinical, O. Recommendations for the use of WBC growth factors: American Society of Clinical Oncology clinical practice guideline update. $\mathrm{J}$ Clin Oncol. 2015;33:3199-212.

73. Souza-Dantas VC, Salluh JI, Soares M. Impact of neutropenia on the outcomes of critically ill patients with cancer: a matched case-control study. Ann Oncol. 2011;22:2094-100.

74. Stocker TJ, Ishikawa-Ankerhold H, Massberg S, Schulz C. Small but mighty: platelets as central effectors of host defense. Thromb Haemost. 2017;117:651-61.

75. Tai E, Guy GP, Dunbar A, Richardson LC. Cost of cancer-related neutropenia or fever hospitalizations, United States, 2012. J Oncol Pract. 2017;13:e552-61.

76. Tak T, Rygiel TP, Karnam G, Bastian OW, Boon L, Viveen M, Coenjaerts FE, Meyaard L, Koenderman L, Pillay J. Neutrophil-mediated suppression of influenzainduced pathology requires CD11b/CD18 (MAC-1). Am J Respir Cell Mol Biol. 2018;58:492-9.

77. Trecarichi EM, Pagano L, Candoni A, Pastore D, Cattaneo C, Fanci R, Nosari A, Caira M, Spadea A, Busca A, Vianelli N, Tumbarello M, Hemabis Registry-Seifem Group, I. Current epidemiology and antimicrobial resistance data for bacterial bloodstream infections in patients with hematologic malignancies: an Italian multicentre prospective survey. Clin Microbiol Infect. 2015;21:337-43.

78. van der Velden WJ, Herbers AH, Netea MG, Blijlevens NM. Mucosal barrier injury, fever and infection in neutropenic patients with cancer: introducing the paradigm febrile mucositis. $\mathrm{Br} \mathrm{J}$ Haematol. 2014;167:441-52.

79. Vincent JL, Moreno R, Takala J, Willatts S, de Mendonca A, Bruining H, Reinhart CK, Suter PM, Thijs LG. The SOFA (Sepsis-related Organ Failure Assessment) score to describe organ dysfunction/failure. On behalf of the Working Group on Sepsis-Related Problems of the European Society of Intensive Care Medicine. Intensive Care Med. 1996;22:707-10.

80. Vos FJ, Bleeker-Rovers CP, Oyen WJ. The use of FDG-PET/CT in patients with febrile neutropenia. Semin Nucl Med. 2013;43:340-8.

81. Walsh TJ, Finberg RW, Arndt C, Hiemenz J, Schwartz C, Bodensteiner D, Pappas P, Seibel N, Greenberg RN, Dummer S, Schuster M, Holcenberg 
JS. Liposomal amphotericin B for empirical therapy in patients with persistent fever and neutropenia. National Institute of Allergy and Infectious Diseases Mycoses Study Group. N Engl J Med. 1999;340:764-71.

82. Walsh TJ, Teppler H, Donowitz GR, Maertens JA, Baden LR, Dmoszynska A, Cornely OA, Bourque MR, Lupinacci RJ, Sable CA, Depauw BE. Caspofungin versus liposomal amphotericin B for empirical antifungal therapy in patients with persistent fever and neutropenia. $N$ Engl $J$ Med. 2004;351:1391-402.

83. Webb BJ, Healy R, Majers J, Burr Z, Gazdik M, Lopansri B, Hoda D, Petersen FB, Ford C. Prediction of bloodstream infection due to vancomycin-resistant enterococcus in patients undergoing leukemia induction or hematopoietic stem-cell transplantation. Clin Infect Dis. 2017;64:1753-9.

84. Weinkove R, Bailey M, Bellomo R, Saxena MK, Tam CS, Pilcher DV, Beasley R, Young PJ. Association between early peak temperature and mortality in neutropenic sepsis. Ann Hematol. 2015;94:857-64.

85. Weinstock DM, Conlon M, Iovino C, Aubrey T, Gudiol C, Riedel E, Young JW, Kiehn TE, Zuccotti G. Colonization, bloodstream infection, and mortality caused by vancomycin-resistant enterococcus early after allogeneic hematopoietic stem cell transplant. Biol Blood Marrow Transplant. 2007;13:615-21.

86. Yadav H, Kor DJ. Platelets in the pathogenesis of acute respiratory distress syndrome. Am J Physiol Lung Cell Mol Physiol. 2015;309:L915-23.

87. Yolin-Raley DS, Dagogo-Jack I, Niell HB, Soiffer RJ, Antin JH, Alyea EP 3rd, Glotzbecker BE. The utility of routine chest radiography in the initial evaluation of adult patients with febrile neutropenia patients undergoing HSCT. J Natl Compr Cancer Netw. 2015;13:184-9. 